ja matkimaan siitä voisi tulla suuri maailmanlaajuinen menestys sirkuksessa. Harmillisesti vain papukaija ei Uspenskin hoidossa opikaan ihmeellisiä taitoja odotetulla tavalla - ja se löytää lopulta uuden kodin anopin luota. Tarinassa tapahtuu vielä loppukäänne, jossa anopin palauttama papukaija oppii kuin oppiikin matkimisen jalon taidon - ja herättää Mäkelän aamuyön tunteina moskovalaisessa kerrostaloasunnossa jäljittelemällä erehdyttävästi työskentelemään ryhtyneen kirjailijan kirjoituskoneen ääntä.

Yleisö pyytää Mäkelää nimeämään lempikirjansa Uspenskin tuotannosta. Sitä ei tarvitse pitkään miettiä: Mäkelän oma suosikki on edelleen ensimmäinen Fedja-setä. Tähän on yleisön helppo yhtyä.

"Sen tasoisen kirjan tekee kirjailija vain yhden elämässään", Käpylän kirjastoyhdistyksen Marja-Leena Mikkola vahvistaa. "Onnittelut sinulle ja suuri onni meille kaikille suomalaislukijoille, että löysit sen kirjan".

Mäkelä tietää hyvin myös Fedja-sedän syntytarinan. Kirjassaan hän kertoo, kuinka Uspenski oli kirjoittanut hahmon alun perin aikuiseksi, mutta mentorina toiminut vanhempi kirjailija kehotti tekemään Fedjasta lapsen. Erinomainen veto on tietenkin se, että setä-nimitys jäi ennalleen ja se onnistuukin kuvamaan hahmoa aika oivallisesti: pikkuvanha Fedja on sangen onnellinen pieni mies. Toisin kuin vaikka Lindgrenin Peppi, joka suunnattomassa vapaudessaan ja anarkiassaan kuitenkin loppujen lopuksi kaipaa vanhempiaan ja huolenpitoa. Fedja puolestaan pärjää itsenäisessä elämässään melko hyvin, keskittyen tekemään aika vastuullisia valintoja. Mäkelän mukaan Fedjan suosion salaisuus on kirjassa kuvattu vapauden kokemus ja kaipuu siihen jokainen lapsi ja aikuinen voi samaistua.

Mäkelällä on myös oma arvionsa siitä, miksi Krokotiili Genan suosio ei ole meillä Suomessa kasvanut aivan samoihin mittoihin: "Krokotiili Genassa byrokratian kritiikki on keskiössä, suuri osa sen huumorista perustuu neuvostotodellisuuden kustannuksella pilailuun. Se ei ole ehkä tuntunut niin tärkeältä meillä”.

Mäkelän mukaan parasta Uspenskin kirjoissa on arvaamattomuus. Kun alkaa lukea, ei voi tietää kuinka tarina päättyy. "Sitä samaa on myös Tove Janssonin Muumi-kirjoissa. Siksi Uspenski ihaili niitä ja arvosti suuresti Janssonia”, Mäkelä toteaa.

Eetu on ensimmäinen ja toistaiseksi ilmeisesti ainoa Eduard Uspenskista kirjoitettu kirja. Se kertoo ehkä jotain siitä hieman ailahtelevaisesta asemasta joka Uspenskille neuvostoaikana ehti muodostua. Varmasti se kertoo myös jotain siitä, miten lastenkulttuurilla ylipäänsä ei ole kovin suuri huomioarvo meidän aikuisten maailmassa. Mäkelä paljastaa, että teos on kuitenkin käännetty myös venäjäksi nimellä Edik vuonna 2008. Eetu-kirjan kirjoittaminen on siten ollut suuri kulttuuriteko rajan molemmin puolin. Kirjailija Uspenski on jo poissa, mutta hänen kirjoituskoneensa ääni kaikuu edelleen.

Ira Österberg

\title{
Pohjoismaiden slavistit koolla Joensuussa
}

Pohjoismainen slavistikongressi (Nordiska Slavistmötet) järjestettiin 21. kerran Joensuussa 14.-18.8.2019. Kolmen vuoden välein järjestettävän konferenssin juuret juontuvat 1950-luvulle saakka, samoin kuin Nordiska slavistförbundetin kansainvälisesti arvostetun, vertaisarvioidun Scando-Slavica -lehden. Aiemmin slavistikongressi on järjestetty Suomessa Turussa, Helsingissä ja Tampereella. Tällä kertaa tapahtuma keräsi kokoon reilut sata slavistiikan alan tutkijaa. Heistä noin kolme neljäsosaa saapui Pohjoismaista, lisäksi osallistujia tuli Venäjältä sekä pienempi joukko myös muualta Euroopasta ja Pohjois-Amerikasta. Tapahtuma keräsi kokeneempien tieteentekijöiden ohella yhteen myös kiitettävästi alan väitöskirjatutkijoita.
Itä-Suomen yliopiston ja Suomen slavistipiiri ry:n järjestämässä tapahtumassa kuultiin monipuolisia esitelmiä eri slaavilaisiin kieliin ja kulttuureihin liittyen. Plenaariesitelmien ja rinnakkaissessioiden lisäksi konferenssin ohjelmaan kuului iltaohjelmaa, vierailu Joensuun taidemuseo Onnissa, Nordiska slavistförbundetin ja sen jäsenjärjestöjen kokouksia sekä retki Kolin kansallispuistoon. Konferenssin kielipaletti oli moninainen: ruotsin, venäjän ja englannin ollessa pääasiallisia käyttökieliä mukana olivat myös mm. norjan- ja ukrainankieliset esitelmät. Monikielisyys heijastui paitsi kahvitauoilla ja illallisilla myös paneelien koostumuksessa.

Esitelmissä tutkimusaiheiden kirjo ulottui kirjallisuudesta morfologiaan, historiasta kään- 
nöstieteisiin sekä monelle muulle alueelle näiden väliin ja liitoskohtiin. Valtaosassa esitelmistä tarkasteltiin Venäjää ja venäjän kieltä, mutta muutkin slaavilaiset kielet ja alueet nousivat esille. Esimerkiksi Jouko Lindstedt (Helsingin yliopisto) plenaaripuheenvuorossaan "Sydligaste Slavia" katsoi pitkällä historiallisella perspektiivillä eteläslaavilaisiin kieli- ja kulttuurialueisiin eri puolilta tulleita vaikutuksia. Lindstedtin lisäksi plenaaripuheenvuoroissa kuultiin Andrei Rogatševskin (Tromssan yliopisto) esitelmä neuvostojohtajien tulkkien työskentelystä ja poliittisesta merkityksestä, Jekaterina Rahilinan (Moskovan talouskorkeakoulu) esitelmä venäjän kielen diskurssiformuloista, Sanna Turoman (Aleksanteri-instituutti) esitelmä venäjän kielen, kirjallisuuden ja kulttuurin tutkimuksen muutoksista eri tieteenalojen vaikuttaessa sen kehitykseen viime vuosikymmeninä, Johanna Nicholsin (Kalifornian yliopisto, Berkeley) esitelmä slaavilaisten kielten verbien stabiliteetista ja muutoksista sekä Julie Hansenin (Uppsalan yliopisto) esitelmä moni- ja limittäiskielisyyden (translingualism) tutkimuksen merkityksestä venäläisen kirjallisuuden tutkimukselle.

Kongressin teeman mukaisesti Pohjoismaiden ja slaavilaisten maiden, kieli- ja kulttuuriyhteydet olivat vahvasti esillä monissa esitelmissä ja paneeleissa. Esimerkiksi käännöstieteilijöistä Alla Kharina (Oslon yliopisto) käsitteli venäjän kielen kulttuurisidonnaisten käsitteiden ja ilmaisujen kääntämistä norjan ja englannin kielille, Tore Nesset (Tromssan yliopisto) norjan kielen yhdyssanojen kääntämistä venäjäksi ja Lisa Mendoza Åsbergin (Tukholman yliopisto) tekstissä esiintyvien dialogia ilmaisevien verbien kääntämistä kieliparin ruotsi-puola välillä.

Käännökset nousivat keskiöön myös kulttuurisuhteita tarkastelleissa esitelmissä. Naisten roolia suomalais-venäläisessä kirjallisuusvaihdossa käsiteltiin paneelissa, jossa puhujina olivat Tintti Klapuri (Helsingin yliopisto), Marja Sorvari (Itä-Suomen yliopisto) ja Arja Rosenholm (Tampereen yliopisto). Tomi Huttusen (Helsingin yliopisto) esitelmä käsitteli venäläisen kirjallisuuden suomentamisen historiaa. Ben Hellmanin (Helsingin yliopisto) aiheena olivat Mihail Šolohovin matkat Eurooppaan ja erityisesti pohjoismaisiin pääkaupunkeihin Tukholmaan ja Kööpenhaminaan. Malin Podlevskikh Karlströmin (Göteborgin yliopisto) esitelmä tarkasteli Ruotsissa käännettyjen venäläisten romaanien kansikuvien ja arvosteluiden välittämiä mielikuvia ja pohti niiden yhteyttä Ruotsissa vallalla olevaan käsitykseen venäläisestä kirjallisuudesta raskaana, vanhahtavana ja korkealle arvostettuna kirjallisuutena.

Tutkimusten lisäksi konferenssissa keskusteltiin ajankohtaisista muutoksista akateemisessa maailmassa. Avoin julkaiseminen muuttaa julkaisutoimintaa kaikkialla, ja ilmiön vaikutusta pohjoismaisten slavistien työhön sekä Nordiska slavistförbundetin Scando-Slavica -lehden tulevaisuuteen pohdittiin tätä varten järjestetyssä pyöreän pöydän keskustelussa. Slavistipiirin järjestämässä paneelissa pohdittiin puolestaan tohtorikoulutuksen tilaa Pohjoismaissa. Tilaisuudessa puhui kaksi jatko-opiskelijaa Ruotsista, kaksi Suomesta ja yksi Norjasta, mutta kuten parhaimmissa paneeleissa aina, keskustelu laajeni koko runsaslukuisen yleisön aktiiviseksi pohdinnaksi ja vertailuksi. Tohtorikoulutuksen suunta koettiin tärkeäksi teemaksi laajemminkin.

Keskustelussa kartoitettiin myös sitä, miten slavistiikka on edustettuna kussakin Pohjoismaassa ja miltä slavistiikan nykytilanne ja tulevaisuus vaikuttavat. Merkittävänä tekijänä nähtiin eräänlainen yhteispohjoismaalainen trendi, jossa slavistiikan, etenkin muiden kieli-ja kulttuurialueiden kuin Venäjän, opiskelijoiden ja siten myös jatko-opiskelijoiden määrät vähenevät. Toisaalta vahvana trendinä tuli esille se, että "slavisteiksi" itsensä määrittelevien jatko-opiskelijoiden tutkimus on yhtä usein ns. perinteistä slavistiikkaa (esim. slaavikielten lingvistiikkaa) kuin se on monitieteistä, mm. yhteiskunta- ja humanistisista tieteistä ammentavaa slaavilaisiin kulttuurialueisiin liittyvää tutkimusta. Tätä "liukumista" edistävät myös institutionaaliset rakenteet: slavistiikan alan jatkoopiskelijamäärien ollessa pienet he osallistuvat muiden, oman tutkimuksen kannalta keskeisten tieteenalojen keskusteluihin, seminaareihin ja konferensseihin. Paneelikeskustelu eteni välillä hyvinkin mielenkiintoiseksi vertailuksi sinänsä pienistä, mutta jatko-opiskelijan ammattiidentiteetin ja kompetenssin kannalta tärkeistä kysymyksistä, kuten rahoitusmalleista, opintojen rakenteesta, opetuksen roolista sekä väitöskirjan kirjoittamiseen varatusta ajasta.

Keskustelun loppuosassa panelistit pohtivat omaa "slavisti-identiteettiään". Yllättävän moni sellainenkin jatko-opiskelija, jonka oma tutkimus on luonteeltaan monitieteistä, tunsi kuitenkin olevansa slavisti ja pitäneensä opintoihinsa kuuluneita slavistiikan kieliopintoja tärkeinä. "Slavistiikka tekee sielulle hyvää" oli yhteinen toteamus paneelin lopuksi.

Slavistiikan alan jatko-opiskelijoiden liikkuvuuden muiden tieteenalojen parissa voi nähdä myönteisenä asiana nykyisessä monitieteisyyttä korostavassa tutkimus(rahoitus)ilmapiirissä, 
mutta samalla panelistit näkivät tarpeen edistää nimenomaan slavistiikan piiriin kuuluvien väitöskirjantekijöiden yhteistyötä. Ideaa lähdettiinkin kehittämään jatko-opiskelijoiden epämuodollisessa illanvietossa, jossa lähestulkoon kaikki konferenssiin osallistuneet jatko-opiskelijat olivat paikalla. Kaikissa Pohjoismaissa tilanne on se, että alan oppiaineet ovat melko pieniä omissa yliopistoissaan, ja valmius etsiä yhteistyökumppaneita maan rajojen ulkopuolelta on suuri, minkä osoitti myös kongressin hyvä osanottajamäärä.

Konferenssin puitteet Itä-Suomen yliopistossa olivat erinomaiset, ja Joensuun maantieteelli- nen läheisyys Venäjään ja sitä kautta slaavilaisen kielen ja kulttuurin näkyvyys kaupungin arjessa toi oman lisänsä aihetta käsittelevään tapahtumaan. Ohjelma oli rakennettu väljäksi niin, että kahvitauoille ja epämuodollisille keskusteluille jäi hyvin tilaa. Toki se tarkoitti myös sitä, että moni osallistuja ei ehtinyt olla paikalla konferenssin alusta aivan sen loppuun. Seuraava, vuonna 2022 järjestettävä Pohjoismainen slavistikongressi pidetään Oslossa.

Susan Ikonen, Eeva Kuikka, Jari Parkkinen \& Mika Perkiömäki

\section{Tuotettuja mielikuvia ja Idäntutkimusta VIETSin kevätseminaarissa 2019}

Venäjästä ja Euroopasta tuotettavia mielikuvia ja todellisuutta tarkasteltiin Venäjän ja Itä-Euroopan tutkimuksen seuran VIETSin vuotuisessa kevätseminaarissa Tieteiden talolla Helsingissä 10. toukokuuta. Seminaarin pääpuhujat olivat kulttuurin ja yhteiskunnan tutkijat Olga Davydova-Minguet (Karjalan tutkimuslaitos, Itä-Suomen yliopisto), Sigrid Kaasik-Krogerus (Musiikin, taiteen ja kulttuurin tutkimuksen laitos, Jyväskylän yliopisto) ja Kaarina Aitamurto (Aleksanteri-instituutti, Helsingin yliopisto).

Olga Davydova-Minguet pohti esityksessään "Voiko maahanmuuttaa historiaan, ja mihin historiaan? Karjalan keskitysleirien transnationaali muisti" maahanmuuton ja kansallisen muistin ja historian välistä suhdetta. Voivatko Suomen venäjänkieliset muuttaa Suomen historiaan? Pitääkö maahanmuuttajien omaksua maahanmuuttomaan käsitys historiasta, ja miten se tapahtuu? Taustana on yhtäältä monisuuntainen ja transnationaali muisti ymmärryksen ja solidaarisuuden tuottajana eri ryhmien välille ja toisaalta suvereeni muisti keskiössään kansakunta.

Tulkinnat Suomen ja Venäjän yhteisestä sotahistoriasta ovat erilaisia rajan eri puolilla. $\mathrm{Ne}$ nousevat esiin muistoa näkyväksi tekevässä työssä ja Suomen venäjänkielisten maahanmuuttajien keskusteluissa. Sodan ja Karjalan keskitysleirien muisto ja historia kyseenalaistavat maahanmuuton historiaan: minkä maan historiaan Suomen venäjänkieliset muutta(isi)vat?

Sodan jälkeisessä Neuvostoliitossa sotamuistoa häivytettiin, ja Suomi oli hyvän naapuruuden mallimaa. Myös kuvat saksalaisista ja suomalaisista miehittäjistä hämärtyivät fasisteiksi. Nyky-Venäjällä sodan muisto on tärkeä poliittinen resurssi. Se myös leviää yli rajojen, kuten Helsinginkin kuolemattoman rykmentin marsseissa, joissa venäläiset kunnioittavat sodassa kuolleiden omaisten muistoa kävelemällä kulkueena heidän valokuviensa kanssa. Karjalan keskitysleirit ovat puolestaan Suomen venäjänkielisten verkkokeskustelujen yksi sota-aihe. Keskusteluihin vaikuttaa esimerkiksi se, miten Venäjän Karjalassa tätä sodan traumaattista kertomusta on välitetty nykyisille sukupolville julkaisujen ja leirien uhreille pystytettyjen muistomerkkien avulla. Yksi aktiivinen toimija Venäjän Karjalasssa on ollut Fasististen keskitysleirien entisten alaikäisten vankien liitto. Suomella on kaksijakoinen asema suhteessa tähän toimintaan, koska kertomukset rakentavat osittain kuvaa fasistisesta Suomesta. Yhtäältä suomalaisten tutkijoiden keräämä tieto ja suomalaiset arkistot ovat olleet tärkeitä tiedonlähteitä sodasta ja leireistä, mutta toisaalta Suomi on kieltäytynyt korvausten maksamisesta leirien uhreille, koska kertomusten tuottamaa kuvaa Suomesta ei pidetä täällä oikeana.

Sigrid Kaasik-Krogerus pohti Euroopan unionin lisääntynyttä kiinnostusta yhteisen kulttuuriperinnön tuottamiseen esityksessään "Eurooppalainen kulttuuriperintötunnus EUkansalaisten silmin". Eurooppalaisen kulttuuriperintötunnuksen (European Heritage Label) tarkoitus on muun muassa vahvistaa Euroopan sisäistä yhtenäisyyttä suurten ongelmien edessä. Tunnuksen avoimen poliittinen tarkoitus on tuottaa eurooppalaista narratiivia, korostaa kohteiden merkitystä ja kansalaisten tunnetta Eurooppaan kuulumisesta. 